\title{
Determining optimum rate of boron application for higher yield of wheat in Old Brahmaputra Floodplain soil
}

\author{
M. R. Debnath ${ }^{1}$, M. Jahiruddin ${ }^{1}$, M. M. Rahmanªnd M. A. Haque ${ }^{2}$ \\ ${ }^{1}$ Department of Soil Science, Bangladesh Agricultural University, Mymensingh and ${ }^{2}$ Department of Soil Science, \\ Patuakhali Science and Technology University, Patuakhali Email: m_jahiruddin@yahoo.com
}

\begin{abstract}
The effect of different rates of boron application on wheat cv. Bijoy was studied through a field experiment at Bangladesh Agricultural University (BAU) farm, Mymensingh during 2009-10 rabi season. The BAU farm belongs to Old Brahmaputra Floodplain agroecological zone (AEZ 9). Texturally the soil was silt loam, with $7.2 \mathrm{pH}, 0.81 \%$ organic matter and $0.15 \mathrm{mg} \mathrm{kg}^{-1}$ available boron content. The experiment was laid out in a randomized complete block design with five boron rates and four replications. Boron rates were $0,0.75,1.5,2.25$ and $3.0 \mathrm{~kg} \mathrm{ha}^{-1}$, with boric

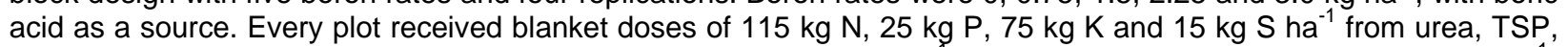
MoP and gypsum, respectively. Treatment receiving B @ $2.25 \mathrm{~kg} \mathrm{ha}^{-1}$ produced the highest grain yield (4.22 $\mathrm{t}$ ha $\left.{ }^{-1}\right)$ which was statistically identical with that obtained with $1.75 \mathrm{~kg} \mathrm{~B} \mathrm{ha}^{-1}$. However, the crop response curve showed $1.90 \mathrm{~kg} \mathrm{ha}^{-1}$ to be the optimum boron rate for the maximization of wheat yield. The lowest grain yield (2.84 t/ha) was recorded with control treatment. There was a positive relationship between grain yield and number of grains spike ${ }^{-1}$. Boron had significant influence on N, P, K, S and B uptake by the crop which, in deed, was more influenced by crop yield and less by nutrient concentration, except $\mathrm{N}$ and $\mathrm{B}$ uptake where concentration had more influence than yield.
\end{abstract}

Keywords: Boron, Floodplains, Wheat

\section{Introduction}

Wheat, next to rice, is the second most important cereal crop in Bangladesh. Despite the constraint that winter in Bangladesh is short and mild compared to the traditional wheat growing countries in the world, the crop has nicely adapted to this country's climate. In order to meet the food deficit in Bangladesh and to cope with the food demand for the increasing population, wheat cultivation deserves due attention.

With advancement of time, new nutrient deficiency has arisen in Bangladesh soils which is mainly due to the increasing cropping intensity, accompanied with the use of modern varieties. Before 1980, deficiencies of $\mathrm{N}, \mathrm{P}$ and $\mathrm{K}$ were the major nutrient deficiency in crops. During early $1980 \mathrm{~s}, \mathrm{~S}$ and $\mathrm{Zn}$ deficiencies were recognized and in 1990, B deficiency was reported on some soils and crops.

The yield of wheat in Bangladesh is low which can be attributed to boron deficiency (Jahiruddin et al., 1992a,b, 1995). Rerkasem et al. (1993) found that in B deficient wheat, the pollen did not accumulate starch and the nuclei, when present, was abnormal. Boron requirement may vary among plant species and also within the genotype of a species (Rerkasem, 2002). Boron deficiency causes grain sterility in wheat as reported by Li et al. (1978) in China, Mandal and Das (1988) in India, Rerkasem et al. (1989) in Thailand, Sthapit (1988) in Nepal and Jahiruddin et al. (1992a) in Bangladesh. Reproductive growth, especially flowering, fruit and seed set are more sensitive to B deficiency than vegetative growth (Noppakoonwong et al., 1997).

The range between deficiency and toxicity of $B$ is quite narrow and an application of $B$ can be extremely toxic to plant at concentrations only slightly above the optimum rate (Gupta et al., 1985). As general guidelines for B fertilizer recommendations, Cooke (1982) suggests that when the hot water soluble B in soil is less than $0.5 \mathrm{mg} \mathrm{kg}^{-1}$, deficiency is likely to occur and all crops are to be treated with $\mathrm{B}$; when it is 0.5-1.0 mg kg $^{-1} \mathrm{~B}$, deficiency may appear and insurance dressings are to be considered; when it is more than $1.0 \mathrm{mg} \mathrm{kg}^{-1} \mathrm{~B}$, deficiency is unlikely and B treatment is not necessary; and when it is $3-5 \mathrm{mg} \mathrm{kg}^{-1} \mathrm{~B}$, crops may be poisoned from excess $B$. Thus, a careful and judicious application of boron is necessary for achieving higher and sustainable crop yield.

The present investigation was, therefore, undertaken to find out an optimum rate of boron application in soil to obtain higher and sustainable yield of wheat. 


\section{Materials and Methods}

The experiment was conducted at the Soil Science Field Laboratory of Bangladesh Agricultural University (BAU) farm, Mymensingh during 2009-10 rabi season. Experimental field was a medium high land under the AEZ 9, Old Brahamaputra Floodplain (UNDP and FAO, 1988). Texturally the soil was silt loam. It contained $7.2 \mathrm{pH}, 0.81 \%$ organic matter, $0.06 \%$ total $\mathrm{N}, 7.29 \mathrm{mg} \mathrm{kg}^{-1}$ available $\mathrm{P}, 0.06 \mathrm{c} \mathrm{mol} \mathrm{kg}{ }^{-1}$ available $\mathrm{K}, 10.0 \mathrm{mg} \mathrm{kg}^{-1}$ available $\mathrm{S}, 0.84 \mathrm{mg} \mathrm{kg}^{-1}$ available $\mathrm{Zn}$ and $0.15 \mathrm{mg} \mathrm{kg}^{-1}$ available B contents. The crop variety was Bijoy (BARI Gom-23). The experiment was laid out in a randomized complete block design $(R C B D)$ with four replications, each plot being $4 \mathrm{~m} \times 4 \mathrm{~m}$. There were five boron rates- $0,0.75,1.50,2.25$ and $3.00 \mathrm{~kg} \mathrm{~B} \mathrm{ha}^{-1}$. Besides boron, every treatment had received $115 \mathrm{~kg} \mathrm{~N}, 25 \mathrm{~kg} \mathrm{P}, 75 \mathrm{~kg} \mathrm{~K}$ and $15 \mathrm{~kg} \mathrm{~S}$ $\mathrm{ha}^{-1}$. Urea, TSP, MoP, gypsum and boric acid were used as sources for N, P, K, S, and B, respectively. The one-third dose of urea and full dose of all other fertilizers were applied as basal to all 20 plots during final land preparation. The second split of urea was applied after 30 days of sowing (crown root stage) and the third split after 56 days (booting stage). Wheat seeds were sown continuously in $20 \mathrm{~cm}$ apart lines at a rate of $125 \mathrm{~kg} \mathrm{ha}^{-1}$. Two irrigations were provided during whole crop growth, one 24 days and other 55 days after sowing. Other intercultural operations viz. weeding and insecticide spray were made whenever required. The crop was harvested at maturity. Data on the yield and yield contributing characters were recorded. Grain and straw samples from every plot were analyzed for N, P, K, S and B levels. Nutrient uptake was calculated using the data of grain and straw yields and their nutrient concentration. All data were statistically analyzed using MSTAT computer software program. Mean comparisons of the treatments were made by the Duncan's Multiple Range Test (Gomez and Gomez, 1984).

\section{Results and Discussion}

Effects of boron application on growth, yield components, yield, and nutrient concentration and uptake was significant in most cases. Results are presented in Tables 1-4 and Fig. 1.

\section{Effects on the growth and yield components of wheat}

Boron application had no significant effect on the plant height of wheat cv. Bijoy (Table 1) showing a range of 89.7-97.3 cm over the five $B$ treatments. The spike length significantly varied with $B$ treatments, with the highest length $(11.6 \mathrm{~cm})$ recorded in $2.25 \mathrm{~kg} \mathrm{ha}^{-1} B$ treatment and the lowest length $(10.3 \mathrm{~cm})$ in $\mathrm{B}$ control. The number of effective tillers plant ${ }^{-1}$ did not respond significantly to the $\mathrm{B}$ treatments. The number of spikelets spike ${ }^{-1}$ also did not vary significantly due to different $B$ rates (Table 1 ). Boron treatments resulted in a significant improvement in the number of grains spike ${ }^{-1}$ (Table 1), showing a range of 29.8 to 38.5 . Treatment receiving $2.25 \mathrm{~kg} \mathrm{~B} \mathrm{ha}^{-1}$ had the highest number of grains spike ${ }^{-1}$ and the B control had the lowest number. There was no significant effect of boron application on 1000-grain weight which was 35.8 to $36.0 \mathrm{~g}$ across the treatments (Table 1).

Table 1. Effects of different rates of boron application on growth, yield and yield contributing characters of wheat

\begin{tabular}{|c|c|c|c|c|c|c|c|c|}
\hline Boron rates & $\begin{array}{c}\text { Plant } \\
\text { height } \\
(\mathrm{cm})\end{array}$ & $\begin{array}{l}\text { Spike } \\
\text { length } \\
(\mathrm{cm})\end{array}$ & $\begin{array}{c}\text { Effective } \\
\text { tillers } \\
\text { plant }^{-1}\end{array}$ & $\begin{array}{l}\text { Spikelets } \\
\text { spike }^{-1}\end{array}$ & $\begin{array}{c}\text { Filled } \\
\text { grains } \\
\text { spike }^{-1} \\
\end{array}$ & $\begin{array}{c}\text { 1000- } \\
\text { grain } \\
\text { weight }(\mathrm{g})\end{array}$ & $\begin{array}{c}\text { Grain } \\
\text { yield } \\
\left.(\mathrm{t} \mathrm{ha})^{-1}\right)\end{array}$ & $\begin{array}{c}\text { Straw } \\
\text { yield } \\
\left(\mathrm{t} \mathrm{ha}^{-1}\right)\end{array}$ \\
\hline B control & 89.7 & $10.4 \mathrm{~b}$ & 4.55 & 16.6 & $29.8 \mathrm{c}$ & 35.8 & $2.84 \mathrm{C}$ & 4.35 \\
\hline $0.75 \mathrm{~kg} \mathrm{~B} \mathrm{ha}^{-1}$ & 91.4 & $10.3 \mathrm{~b}$ & 3.65 & 16.0 & $30.3 \mathrm{c}$ & 36.0 & $3.47 \mathrm{~b}$ & 4.40 \\
\hline $1.5 \mathrm{~kg} \mathrm{~B} \mathrm{ha}^{-1}$ & 92.5 & $10.9 \mathrm{ab}$ & 3.30 & 16.6 & $33.8 \mathrm{~b}$ & 36.0 & $4.14 \mathrm{a}$ & 4.44 \\
\hline $2.25 \mathrm{~kg} \mathrm{~B} \mathrm{ha}^{-1}$ & 97.3 & $11.6 \mathrm{a}$ & 4.00 & 17.2 & $38.5 \mathrm{a}$ & 36.0 & $4.22 \mathrm{a}$ & 4.56 \\
\hline $3.0 \mathrm{~kg} \mathrm{~B} \mathrm{ha}^{-1}$ & 87.2 & $10.3 \mathrm{~b}$ & 3.95 & 16.3 & $33.1 \mathrm{~b}$ & 35.9 & $3.63 \mathrm{~b}$ & 4.40 \\
\hline $\mathrm{CV}(\%)$ & 3.58 & 5.92 & 22.5 & 4.35 & 5.12 & 2.68 & 3.61 & 1.19 \\
\hline SE $( \pm)$ & NS & 0.32 & NS & NS & 0.85 & NS & 0.01 & NS \\
\hline
\end{tabular}

Values in a column having same letter do not differ significantly at $5 \%$ level by DMRT.

$\mathrm{NS}=$ Not significant, $\mathrm{CV}=$ Coefficient of variation, $\mathrm{SE}=$ Standard error of means 


\section{Effects on the grain and straw yields of wheat}

The grain yield of wheat (cv. Bijoy) was significantly influenced by boron application (Table 1). The grain yield increased progressively up to $2.25 \mathrm{~kg} \mathrm{~B} \mathrm{ha}^{-1}$ and thereafter declined at higher rate $\left(3 \mathrm{~kg} \mathrm{~B} \mathrm{ha}^{-1}\right)$. The highest yield (4.22 $\mathrm{t} \mathrm{ha}^{-1}$ ) recorded with $2.25 \mathrm{~kg} \mathrm{~B} \mathrm{ha}^{-1}$ application was statistically identical with that (4.14 $\mathrm{t} \mathrm{ha}^{-1}$ ) noted with $1.5 \mathrm{~kg} \mathrm{ha}^{-1} \mathrm{~B}$ rate. The $\mathrm{B}$ control gave the lowest grain yield $\left(2.84 \mathrm{t} \mathrm{ha}^{-1}\right)$. Yield benefits over control due to boron application @ 0.75, 1.50, 2.25 and $3.00 \mathrm{~kg} \mathrm{~B} \mathrm{ha}^{-1}$ were found as 22.2, 45.8, 48.6 and $27.8 \%$, respectively (Table 1 ).

An attempt has been made to fit the yield data to the quadratic equation- $y=a+b x+c x^{2}$. The equation thus obtained was $y=2.7611+1.465 x-0.3848 x^{2}$ (Fig. 1). From the equation, an optimum $B$ rate that has maximized yield has been computed following the procedure, as outlined by Gomez and Gomez (1984).

Rate of boron that maximizes yield: $B y=\frac{-b}{2 c}$

Where $\mathrm{b}$ and $\mathrm{c}$ were the estimates of the regression coefficient. The By value was estimated as $1.90 \mathrm{~kg}$ $\mathrm{ha}^{-1}$.

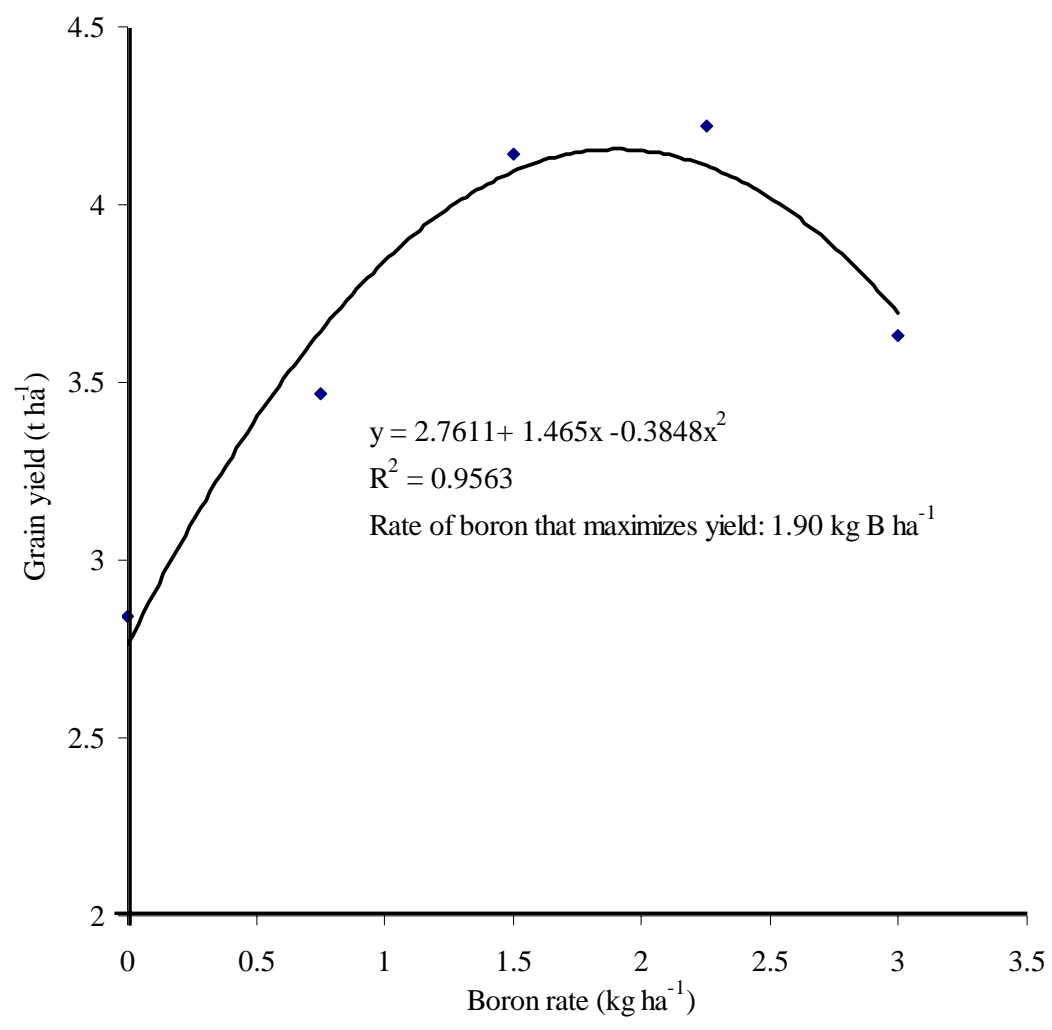

Fig.1 Relationship between grain yield and boron rates

The soil B content $\left(0.15 \mathrm{mg} \mathrm{kg}^{-1}\right.$ hot water extractable B) of wheat field was inadequate to support normal plant growth. Thus, the present experiment shows a good correlation between soil test value and crop response. The higher yield of wheat as obtained with $B$ treatments agrees well to the findings of Ahmed et al. (2008) and Kamal et al. (2009) in Bangladesh, Rerkasem et al. (1989) in Thailand, and Mukherjee and Bhowmik (2008) in India. 
The straw yield of wheat was not influenced by the $B$ treatments (Table 1). The highest straw yield (4.56 $\mathrm{t}$ $\left.\mathrm{ha}^{-1}\right)$ was obtained with $2.25 \mathrm{~kg} \mathrm{ha}^{-1} \mathrm{~B}$ treatment and the lowest $\left(4.35 \mathrm{t} \mathrm{ha}^{-1}\right)$ with control.

Grain yield is a complex character that results from contribution of several plant parameters. The grain yield was positively influenced by spike length $(r=0.48 ; P<0.05)$, filled grains spike ${ }^{-1}(r=0.89 ; P<0.01)$ and 1000-grain weight $(r=0.59 ; P<0.01) \quad($ Table 2$)$. There was a significant and positive correlation between grain and straw yields of wheat $(r=0.69 ; P<0.01)$. This result otherwise indicates that the grain set of wheat is interrupted by boron deficiency and it is possible to overcome this problem by $\mathrm{B}$ application to soil.

Table 2. Correlation matrix among different plant parameters, grain yield and straw yield of wheat $(n=20)$

\begin{tabular}{|l|c|c|c|c|c|c|c|c|}
\hline Variables & $\begin{array}{c}\text { Plant } \\
\text { height }\end{array}$ & $\begin{array}{c}\text { Spike } \\
\text { length }\end{array}$ & $\begin{array}{c}\text { Spikelets } \\
\text { spike }^{-1}\end{array}$ & $\begin{array}{c}\text { Filled } \\
\text { grains } \\
\text { spike }\end{array}$ & $\begin{array}{c}\text { Effective } \\
\text { tillers } \\
\text { hill }^{-1}\end{array}$ & $\begin{array}{c}1000-\text { grain } \\
\text { weight }\end{array}$ & $\begin{array}{c}\text { Grain } \\
\text { yield }\end{array}$ & $\begin{array}{c}\text { Straw } \\
\text { yield }\end{array}$ \\
\hline Plant height & 1 & & & & & & & \\
\hline Spike length & $0.80^{\star \star}$ & 1 & & & & & & \\
\hline Spikelets spike & $0.49^{\star}$ & $0.68^{\star \star}$ & 1 & & & & & \\
\hline Filled grains spike $^{-1}$ & $0.64^{\star \star}$ & $0.63^{\star \star}$ & $0.50^{\star}$ & 1 & & & & \\
\hline Effective tillers hill $^{-1}$ & 0.03 & 0.01 & 0.03 & 0.16 & 1 & & & \\
\hline 1000-grain weight & 0.40 & 0.40 & 0.19 & $0.58^{\star \star}$ & 0.21 & 1 & & \\
\hline Grain yield & 0.44 & $0.48^{\star}$ & 0.42 & $0.89^{\star \star}$ & 0.11 & $0.59^{\star \star}$ & 1 & \\
\hline Straw yield & $0.53^{\star}$ & $0.63^{\star \star}$ & $0.49^{\star \star}$ & $0.66^{\star \star}$ & 0.23 & $0.45^{\star}$ & $0.70^{\star \star}$ & 1 \\
\hline
\end{tabular}

*, $\mathrm{P}<0.05 \quad$ **, $\mathrm{P}<0.01$

\section{Effects on the nutrient concentration of wheat}

The $\mathrm{N}$ concentration of grain remained unaffected by $\mathrm{B}$ treatments (Table 3 ) but in straw the $\mathrm{N}$ concentration markedly varied. The $\mathrm{N}$ concentration in grain varied from $1.94-2.20 \%$ and that in straw from $0.56-0.70 \%$, the lowest $\mathrm{N}$ concentration being recorded with $\mathrm{B}$ control for both plant parts. Boron application had significant effect on the $\mathrm{P}$ concentration of grain and no effect on the $\mathrm{P}$ concentration of straw (Table 3). The grain $P$ concentration ranged between $0.34-0.43 \%$ and straw $P$ 0.03-0.04\%. The highest $P$ concentration both in grain and straw was obtained with B treatment @ $2.25 \mathrm{~kg} \mathrm{ha}^{-1}$ and the lowest $\mathrm{P}$ concentration was recorded with $\mathrm{B}$ control. The $\mathrm{K}$ concentration of wheat grain significantly varied with $\mathrm{B}$ treatments (Table 3 ). The grain $\mathrm{K}$ concentrations over the treatments were $0.39-0.47 \%$. The highest grain $\mathrm{K}$ concentration $(0.47 \%)$ was noted in $3.0 \mathrm{~kg} \mathrm{ha}^{-1} \mathrm{~B}$ treatment and the lowest grain $\mathrm{K}$ concentration in B control. The straw $\mathrm{K}$ concentration was also affected by B application (Table 3), showing the highest $\mathrm{K}$ concentration (1.95\%) in $3.0 \mathrm{~kg} \mathrm{~B} \mathrm{ha}^{-1}$ treatment and the lowest straw $\mathrm{K}$ in control $(1.69 \%)$. The $\mathrm{S}$ concentration of both straw and grain was significantly influenced by the $\mathrm{B}$ treatments (Table 3), the highest grain S concentration being recorded by $2.25 \mathrm{~kg} \mathrm{ha}^{-1} \mathrm{~B}$ rate and the highest straw $\mathrm{S}$ concentration by $3.0 \mathrm{~kg} \mathrm{~B} \mathrm{ha-1}$, with the lowest $S$ concentrations recorded by B control. The grain B concentration was significantly influenced by the $B$ treatments (Table 3 ). Comparing the effects of various rates of $B$ application, the $2.25 \mathrm{~kg} \mathrm{ha}^{-1} B$ rate showed the highest $B$ concentration $\left(16.1 \mu \mathrm{g} \mathrm{g}^{-1}\right)$ in grain and the $B$ control treatment did the lowest $B$ concentration $\left(10.1 \mu \mathrm{g} \mathrm{g}^{-1}\right)$. The grain $B$ concentration in all four B treatments was significantly higher than that in B control. The straw B concentration was also affected by B application (Table 3). The highest and lowest straw B concentrations were 18.1 and $13.1 \mu \mathrm{g}$ $\mathrm{g}^{-1}$ due to $2.25 \mathrm{~kg} \mathrm{~B} \mathrm{ha}^{-1}$ and B control, respectively. 
Table 3. Effects of different rates of boron application on the N,P, K, S and B concentrations of wheat grain and straw

\begin{tabular}{|c|c|c|c|c|c|c|c|c|c|c|}
\hline \multirow{2}{*}{ Boron rates } & \multicolumn{2}{|c|}{$\mathrm{N}(\%)$} & \multicolumn{2}{|c|}{$\mathrm{P}(\%)$} & \multicolumn{2}{|c|}{ K (\%) } & \multicolumn{2}{|c|}{ S (\%) } & \multicolumn{2}{|c|}{$B\left(\mu g g^{-1}\right)$} \\
\hline & Grain & Straw & Grain & Straw & Grain & Straw & Grain & Straw & Grain & Straw \\
\hline B control & 1.94 & $0.56 \mathrm{~d}$ & $0.34 \mathrm{~b}$ & 0.03 & $0.39 \mathrm{c}$ & $1.69 \mathrm{c}$ & $0.07 \mathrm{c}$ & $0.06 \mathrm{c}$ & $10.1 \mathrm{e}$ & $13.1 \mathrm{e}$ \\
\hline $0.75 \mathrm{~kg} \mathrm{~B} \mathrm{ha}^{-1}$ & 2.12 & $0.60 \mathrm{c}$ & $0.38 \mathrm{~b}$ & 0.03 & $0.42 \mathrm{bc}$ & $1.70 \mathrm{c}$ & $0.08 \mathrm{~b}$ & $0.07 \mathrm{bc}$ & $13.1 \mathrm{~d}$ & $15.0 \mathrm{c}$ \\
\hline $1.5 \mathrm{~kg} \mathrm{~B} \mathrm{ha}^{-1}$ & 2.17 & $0.63 \mathrm{~b}$ & $0.39 a b$ & 0.03 & $0.41 \mathrm{c}$ & $1.78 \mathrm{~b}$ & $0.08 \mathrm{ab}$ & $0.07 \mathrm{~b}$ & $15.1 \mathrm{~b}$ & $15.9 \mathrm{~b}$ \\
\hline $2.25 \mathrm{~kg} \mathrm{~B} \mathrm{ha}^{-1}$ & 2.20 & $0.70 \mathrm{a}$ & $0.43 a$ & 0.04 & $0.44 \mathrm{~b}$ & $1.81 \mathrm{~b}$ & $0.09 a$ & $0.07 \mathrm{~b}$ & $16.1 \mathrm{a}$ & $18.1 \mathrm{a}$ \\
\hline $3.0 \mathrm{~kg} \mathrm{~B} \mathrm{ha}^{-1}$ & 2.15 & $0.63 \mathrm{~b}$ & $0.39 \mathrm{ab}$ & 0.03 & $0.47 \mathrm{a}$ & $1.95 \mathrm{a}$ & $0.08 a b$ & $0.08 \mathrm{a}$ & $14.2 \mathrm{c}$ & $14.8 \mathrm{~d}$ \\
\hline CV(\%) & 5.71 & 2.86 & 9.09 & 25.8 & 4.05 & 1.83 & 4.40 & 4.55 & 2.03 & 0.5 \\
\hline SE ( $( \pm)$ & NS & 0.01 & 0.02 & NS & 0.01 & 0.02 & 0.01 & 0.01 & 0.14 & 0.04 \\
\hline
\end{tabular}

Values in a column having same letter do not differ significantly at $5 \%$ level by DMRT.

$\mathrm{NS}=$ Not significant, $\mathrm{CV}=$ Coefficient of variation, $\mathrm{SE}=$ Standard error of means

\section{Effects on the nutrient uptake by wheat}

The $\mathrm{N}$ uptake by wheat grain was significantly influenced by the different $\mathrm{B}$ treatments (Table 4). The $\mathrm{N}$ uptake by grain varied from $55.1-92.8 \mathrm{~kg} \mathrm{ha}^{-1}$, the highest $\mathrm{N}$ uptake was recorded by $2.25 \mathrm{~kg} \mathrm{ha}^{-1} \mathrm{~B}$ treatment and the lowest $\mathrm{N}$ uptake by the $\mathrm{B}$ control. Similar result was observed in straw $\mathrm{N}$ uptake as well as total $\mathrm{N}$ uptake by the crop. The $\mathrm{P}$ uptake by both grain and straw significantly differed with $\mathrm{B}$ treatments. In both cases, the lowest $P$ uptake was found in B control and the highest $P$ uptake in $2.25 \mathrm{~kg}$ $\mathrm{ha}^{-1} \mathrm{~B}$ treatment. The total $\mathrm{P}$ uptake was also significantly and positively influenced by the boron treatments (Table 4). The $\mathrm{K}$ uptake by grain and straw also significantly increased due to different rates of $\mathrm{B}$ application (Table 4). The $\mathrm{K}$ uptake by grain ranged from $11.1-18.5 \mathrm{~kg} \mathrm{ha}^{-1}$, the highest $\mathrm{K}$ uptake being noted with $2.25 \mathrm{~kg} \mathrm{~B} \mathrm{ha}^{-1}$ and the lowest with $\mathrm{B}$ control. The $\mathrm{K}$ uptake by straw varied between 73.4 and $85.7 \mathrm{~kg} \mathrm{ha}^{-1}$. The treatment receiving B @ $3.0 \mathrm{~kg} \mathrm{ha}^{-1}$ demonstrated the highest $\mathrm{K}$ uptake by straw and the treatment receiving no $\mathrm{B}$ dose exhibited the lowest $\mathrm{K}$ uptake. The $\mathrm{S}$ uptake by grain and straw was significantly influenced by $B$ application (Table 4). In case of grain $S$ uptake, the highest uptake was found in $2.25 \mathrm{~kg} \mathrm{~B} \mathrm{ha}^{-1}$ treatment and the lowest $S$ uptake in B control. On the other hand, the highest and lowest straw S uptake was observed in $3.0 \mathrm{~kg} \mathrm{~B} \mathrm{ha}^{-1}$ and $\mathrm{B}$ control, respectively. As expected, B application had significant and positive effect on the B uptake by grain and straw (Table 4). In both cases, the lowest B uptake was found in B control and the highest in treatment having B @ $2.25 \mathrm{~kg} \mathrm{ha}^{-1}$.

Table 4. Effects of different rates of boron application on the $N, P, K, S$ and $B$ uptake of wheat

\begin{tabular}{|c|c|c|c|c|c|c|c|c|c|c|c|c|c|c|c|}
\hline \multirow[t]{2}{*}{ Boron rates } & \multicolumn{3}{|c|}{ N uptake $\left(\mathrm{kg} \mathrm{ha}^{-1}\right)$} & \multicolumn{3}{|c|}{$\mathrm{P}$ uptake $\left(\mathrm{kg} \mathrm{ha}^{-1}\right)$} & \multicolumn{3}{|c|}{ K uptake $\left(\mathrm{kg} \mathrm{ha}^{-1}\right)$} & \multicolumn{3}{|c|}{ S uptake (kg ha-1) } & \multicolumn{3}{|c|}{ B uptake $\left(\mathrm{g}\right.$ ha $\left.^{-1}\right)$} \\
\hline & Grain & Straw & Total & Grain & Straw & Total & Grain & Straw & Total & Grain & Straw & Total & Grain & Straw & Total \\
\hline B control & $55.1 \mathrm{c}$ & $24.4 \mathrm{~d}$ & $79.5 \mathrm{c}$ & $9.85 \mathrm{c}$ & $1.20 \mathrm{~b}$ & $11.1 \mathrm{c}$ & $11.1 \mathrm{~d}$ & $73.4 \mathrm{~d}$ & $84.5 \mathrm{c}$ & $1.95 d$ & $2.60 \mathrm{~d}$ & $4.55 \mathrm{e}$ & $28.8 \mathrm{~d}$ & $57.0 \mathrm{~d}$ & $85.7 \mathrm{~d}$ \\
\hline $0.75 \mathrm{~kg} \mathrm{~B} \mathrm{ha}^{-1}$ & $73.6 \mathrm{~b}$ & $26.4 \mathrm{C}$ & $100.0 \mathrm{~b}$ & $13.2 \mathrm{~b}$ & $1.21 \mathrm{~b}$ & $14.4 \mathrm{C}$ & $14.6 \mathrm{c}$ & $74.7 \mathrm{~d}$ & $89.3 \mathrm{c}$ & $2.78 \mathrm{c}$ & $2.80 \mathrm{C}$ & $5.58 \mathrm{~d}$ & $45.5 \mathrm{c}$ & $65.8 \mathrm{c}$ & $111.3 \mathrm{c}$ \\
\hline $1.5 \mathrm{~kg} \mathrm{~B} \mathrm{ha}^{-1}$ & $89.8 \mathrm{a}$ & $28.1 b$ & $117.9 \mathrm{a}$ & $16.1 \mathrm{ab}$ & 1.33ab & $17.4 \mathrm{~b}$ & $17.0 \mathrm{~b}$ & $79.0 \mathrm{c}$ & $96.0 \mathrm{~b}$ & $3.31 b$ & $2.98 \mathrm{~b}$ & $6.29 \mathrm{c}$ & $62.5 \mathrm{a}$ & $70.4 \mathrm{~b}$ & $132.9 \mathrm{~b}$ \\
\hline $2.25 \mathrm{~kg} \mathrm{~B} \mathrm{ha}^{-1}$ & $92.8 \mathrm{a}$ & $31.6 \mathrm{a}$ & $124 \mathrm{a}$ & $18.1 \mathrm{a}$ & $1.82 \mathrm{a}$ & $19.9 a$ & $18.5 \mathrm{a}$ & $82.4 \mathrm{~b}$ & $101 \mathrm{a}$ & $3.73 \mathrm{a}$ & $3.07 \mathrm{~b}$ & $6.80 \mathrm{a}$ & $67.9 \mathrm{a}$ & $82.5 \mathrm{a}$ & $150 \mathrm{a}$ \\
\hline $3.0 \mathrm{~kg} \mathrm{~B} \mathrm{ha}^{-1}$ & $77.9 \mathrm{~b}$ & $27.8 \mathrm{~b}$ & $106 \mathrm{~b}$ & $14.0 \mathrm{~b}$ & $1.32 \mathrm{ab}$ & $15.4 \mathrm{~b}$ & $17.1 \mathrm{~b}$ & $85.7 \mathrm{a}$ & $103 a$ & $3.03 \mathrm{~b}$ & $3.41 \mathrm{a}$ & $6.44 \mathrm{~b}$ & $51.5 \mathrm{~b}$ & $64.9 \mathrm{c}$ & $116 \mathrm{c}$ \\
\hline $\mathrm{CV}(\%)$ & 8.00 & 3.00 & 5.56 & 10.6 & 26.3 & 10.8 & 5.53 & 1.89 & 2.03 & 6.25 & 3.07 & 3.53 & 3.84 & 1.10 & 1.50 \\
\hline SE $( \pm)$ & 2.93 & 0.41 & 2.80 & 0.71 & 0.19 & 0.80 & 0.41 & 0.75 & 0.96 & 0.09 & 0.05 & 0.10 & 0.93 & 0.38 & 0.87 \\
\hline
\end{tabular}

Values in a column having same letter do not differ significantly at $5 \%$ level by DMRT.

NS= Not significant, $C V=$ Coefficient of variation, $S E=$ Standard error of means

\section{Conclusion}

The Old Brahmaputra Floodplain soil (AEZ 9) is deficient in boron and thus, to meet this element deficiency and ensure higher wheat yield, the soil needs to be supplied with boron @ $1.90 \mathrm{~kg} \mathrm{ha}^{-1}$.

\section{Acknowledgement}

The authors gratefully acknowledge the financial support provided by the USDA through the project "Screening, selection and molecular characterization of boron efficient wheat genotypes" to carry out this work. 


\section{References}

Ahmed, A.H.H., Harb, E.M., Higazy, M.A. and Morgan, S.H. 2008. Effect of silicon and boron foliar applications on wheat plants grown under saline soil conditions. Inter. J. Agric. Res. 3(1): 1-26.

Cooke, G.W. 1982. Fertilizing for Maximum Yield. Granada, UK. p 465.

Gomez, K.A. and Gomez, A.A. 1984. Statistical Procedures for Agricultural Research. $2^{\text {nd }}$ Edt. A Wiley Inter Sci. Publi. John Wiley \& Sons., New York.

Gupta, U.C., Jame, Y.W., Cambell, C.A., Leyshon, A.J. and Nicholaichuk, W. 1985. Boron and its role in crop production. Canad. J. Soil Sci. 65:381.

Jahiruddin, M., Ali, M.S., Hossain, M.A., Ahmed, M.U. and Hoque, M.M. 1995. Effect of boron on grain set, yield and some other parameters of wheat cultivars. Bangladesh J. Agric. Sci. 22(1): 179-184.

Jahiruddin, M., Abedin, M.J. and Ahmed, M.U. 1992a. Boron deficiency- A major factor for grain sterility in wheat. Proc. of the interCongress Conference of Commission IV, December 1-3, pp. 85-92.

Jahiruddin, M., Hoque, M.S., Haque, A.K.M.M. and Roy, P.K. 1992b. Influence of boron, copper and molybdenum on grain formation in wheat. Crop Res. 5: 35-42.

Kamal, M.A., Jahiruddin, M., Moslehuddin, A.Z.M. and Islam, S. 2009. Comparative performances of different methods of boron application on the yield and nutrient uptake of wheat. J. Bangladesh Soc. Agric. Sci. Technol. 6(3\&4):75-78.

Li, W.H., Kui, M.C., Chao, N.S., Jern, M.P., Li, C.R., Chu, W.J. and Wang, C.L. 1978. Studies on the cause of sterility in wheat. J. Northern Agric. College 3: 1-19.

Mandal, A.B. and Das, A.D. 1988. Response of wheat (Triticum aestivum) to boron application. Indian J. Agric. Sci. 58(9): 681-683.

Mukherjee, S. and Bhowmik, N. 2008. Comparative performance of genotypes of wheat (Triticum aestivum L.) for-boron induced sterility in the tarai region of West Bengal, India. Environ. Ecol. 26(1): 117-120.

Noppakoonwong, R.N., Rerkasem, B., Bell, R.W., Dell, B. and Loneragan, J.F. 1997. Prognosis and diagnosis of boron deficiency in black gram (Vigna mungo L. Hepper) in the field by plant analysis. Kluwer Aca. Pub., Dordrecht, The Netherlands. pp. 8994 ,

Rerkasem, B. 2002. Boron nutrition of crops and genotypic variation in boron efficiency. In: Boron in Plant and Animal Nutrition, Goldbatch et al (Ed.) pp. 269-280, Kluwer Aca. Pub., New York.

Rerkasem, B., Netsangtip, R., Lordkaew, S. and Cheng, C. 1993. Grain set failure in boron deficient wheat. In proc: twelfth International Plant Nutrition Colloquim, N. J. Barrow (ed.), pp. 401-404.

Rerkasem, B., Saunders, D.A. and Dell, B. 1989. Grain set failure and boron deficiency in wheat. Thailand. J. Agric. 5: 1-10.

Sthapit, N.R. 1988. Studies on wheat sterility problems in the Hills, Tar and Tarai of Nepal, Lumple Agric. Centre, Tech. Pap. No. $16 / 88$. 